\title{
Penyusunan Laporan Keuangan Berdasarkan Standar Akuntansi Keuangan Entitas Mikro, Kecil dan Menengah (SAK EMKM) pada Bank Sampah Kalibukbuk Bersih (KALIBER) di Desa Kalibukbuk Kec/Kab Buleleng
}

\author{
Putu Santiani $^{1 *}$, I Gede Putu Banu Astawa² ${ }^{2}$ iD \\ 12 Jurusan Ekonomi dan Akuntansi, Universitas Pendidikan Ganesha, Singaraja, Bali, Indonesia \\ *santiani.id02@gmail.com ${ }^{1 *}$
}

\section{Abstrak}

Dari penelitian yang dilakukan pada Bank Sampah KALIBER menunjukkan bila nasabah bank sampah KALIBER selalu mengalami peningkatan tiap tahunnya, namun sangat disayangkan sekali bila pada bank sampah KALIBER belum membuat laporan keuangan sesuai dengan SAK-EMKM. Sehingga penelitian ini dilakukan dengan tujuan untuk menyusun Laporan Keuangan Berdasarkan Standar Akuntansi Keuangan Entitas Mikro,Kecil dan Menengah (SAK EMKM) pada Bank Sampah Kalibukbuk Bersih (KALIBER) di Desa Kalibukbuk Kec/Kab Buleleng. Metode penelitian yang dilakukan menggunakan metode kualitatif dengan teknik pengumpulan data melalui wawancara,observasi,studi pustaka, dan dokumentasi. Dari permasalahan yang ditemui maka yang mejadi solusi adalah pembuatan laporan keuangan yang sesuai dengan SAK-EMKM dengan memperoleh hasil pada laporan laba rugi selama bulan Juli - 31 Desember 2020 sebesar Rp 2.176.200 dan untuk laporan neraca/posisi keuangan menunjukkan jumlah aktiva dan pasiva sebesar Rp 120.215.525

Kata Kunci : Bank sampah,SAK EMKM, laporan keuangan.

\section{Abstract}

From research conducted at the KALIBER Waste Bankit shows that the KALIBER waste bank customers always increase every year, but it is very unfortunate if the KALIBER waste bank has not made financial reports in accordance with SAK-EMKM. So this research was conducted with the aim of compiling Financial Statements Based on Financial Accounting Standards for Micro, Small and Medium Entities (SAK EMKM) at the Clean Kalibukbuk Waste Bank (KALIBER) in Kalibukbuk Village, Buleleng city. The research method is carried out using qualitative methods using data collection techniques through interviews, observations, literature studies, and documentation. From the problems encountered, the solution is to prepare financial statements in accordance with SAK-EMKM by obtaining results on the income statement for July - December 31, 2020 amounting to $R p 2.176 .200$ and for the balance sheet/financial position report showing the total assets and liabilities of $R p$ 120.215.525.

Keywords: Waste bank, SAK EMKM, financial reports

\section{Pendahuluan}

Di Indonesia jumlah sampah yang ada selalu mengalami peningkatan hal ini disebabkan oleh semakin meningkatnya jumlah penduduk yang diimbangi pula dengan peningkatkan konsumsi masyarakat (Azzahra 2020). Menurut Undang-Undang Nomor 18 Tahun 2008 menyatakan bila sampah merupakan buangan yang dihasilkan dari aktifitas yang dilakukan setiap hari dan juga dihasilkan dari aktifitas alam . Menurut Ayu Ningthias (2018) pemecahan permasalahan sampah yang menjadi solusi saat ini yaitu dibakar, cara ini sering diterapkan oleh masyrakat karena dipandang lebih baik hal ini disebabkan karena sampah yang begitu banyak terkumpul bisa hilang dalam waktu yang sangat cepat. Namun apabila

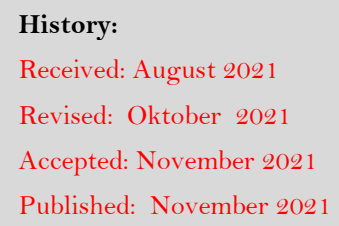


hal ini terus dilakukan akan memberikan dampak negatif bukan hanya bagi kesehatan lingkungan namun juga berpengaruh pada kesehatan manusia (Sekar ayuning thias 2018).

Untuk memnimilasir permasalahan tersebut maka penting untuk adanya pengelolaan sampah dari sumbernya. Hal ini sesuai dengan PP No.13 Thn 2012 yang mengamanatkan pentingnya untuk menangani permasalahan sampah dari dasarnya yang mana pengelolaan yang biasanya dari kumpul-angkut-buang menjadi pengelolaan sampah yang berpusat pada penanganan permasalahan dan pengurangan sampah. Sehingga melalui bank sampah, sampah yang pada umumnya tidak memiliki nilai ekonmis dapat dirubah menjadi sesuatu baik itu berupa barang hingga memiliki nilai jual.

Bank Sampah pada dasarnya adalah sebuah komunitas yang memberdayakan sampah untuk bernilai ekonomi dengan sistem yang dimiliki seperti perbankan (Fitria 2017). Untuk di Provinsi Bali Jumlah bank sampah sudah mencapai 1092 ditahun 2019 (Dinas Lingkungan Hidup Kabupaen Buleleng 2019). Khusus untuk di Kabupaten Buleleng jumlah Bank Sampah dari tahun 2015-2020 selalau mengalami peningkatan. Ditahun 2015 sudah terdapat 4 bank sampah hingga ditahun 2020 jumlah bank sampah yang ada sudah mencapai 64 bank sampah unit.

Hal ini menunjukkan bila perminatan bank sampah di kabupaten Buleleng dari tahun 2015-2020 selalu mengalami peningkatan. Hal ini menjadi bukti bila Usaha Mikro, Kecil, dan Mengenah (UMKM) yang ada di Indonesia khusunya di Kabupaten Buleleng mengalami pertumbuhan. Pemerintah selalu berupaya untuk membantu para pelaku UMKM dari segi sistem keuangan pencatatan yang seharusnya diterapkan(Undang-Undang Republik Indonesia No 20 Tentang UMKM, 2008) . Usaha mikro,kecil dan menengah diatur oleh standar SAK ETAP namun karena dalam penggunaannya SAK ETAP masih dirasa rumit untuk UMKM itu sendiri sehingga pemerintah mengesahkan dan menerbitkan SAK EMKM yang mana standar ini sasarannya adalah para pelaku bisnis yang belum membuat pencatatan akuntansi sesuai dengan SAK EMKM. Dengan diberlakukannya undang-undang tersebut dapat menopang UMKM yang ada agar lebih baik dalam pengelolaan keuangan sehingga meningkatkan pendapatan masyrakat serta terciptanya lapangan pekerjaan.

Bank sampah Kalibukbuk Bersih (KALIBER) merupakan salah satu bank sampah yang ada di kabupaten Buleleng yang keberadaannya cukup dilirik oleh masyarakat hal ini disebabkan karena banyaknya program-program inovatif yang dimiliki oleh bank sampah KALIBER sehingga bank sampah KALIBER memperoleh beberapa penghargaan dan tiap tahunnya selalu menglami peningkatan jumlah nasabah. Dengan meningkatnya jumlah bank sampah yang diikuti pula peningkatan nasabah pada bank sampah sehingga aktivitas pada bank sampah semakin banyak dan saat ini kebutuhan transparansi keuangan menjadi hal yang penting untuk diterapkan hal ini bertujuan untuk meningkatkan kepercayaan masyarakat terhadap pencatatan yang dilakukan oleh bank sampah. Dengan menerapkan transparansi keuangan diyakini dapat meningkatkan kepercayaan dan jumlah nasabah pada bank sampah akan mengalami peningkatan pula. Unsur tersebut menjadi alasan yang perlu dipertimbangkan demi perkembangan bank sampah kedepannya.

Namun permasalah yang ditemui yaitu pada bank sampah KALIBER belum membuat pencatatan akuntansi sesuai dengan siklus akuntansi hingga belum dibuatnya laporan keuangan dengan SAK EMKM. Pada bank sampah KALIBER hanya sebatas mencatat jumlah sampah yang diterima dari masing-masing nasabah tanpa melakukan pencatatan lebih lanjut maka dari itu penting untuk dilakukan penelitian mengenai Penyusunan Laporan Keuangan Berdasarkan Standar Akuntansi Keuangan Entitas Mikro, Kecil Dan Menengah (SAK-EMKM) pada Bank Sampah Kalibukbuk Bersih (KALIBER) di Desa Kalibukbuk $\mathrm{Kec} / \mathrm{Kab}$ Buleleng. Dalam penyusunan laporan keuangan dengan SAK-EMKM penulis menggunakan landasan teori yang mendukung yaitu teori agensi yang menyatakan adanya 
hubungan antara pemeberi kerja dengan pekerja yang mana hubungan ini diikat pada kontrak, teori sinyal yang mana teori ini menyatakan pentingnya suatu perusahaan dalam memberikan informasi keuangan sebagai suatu sinyal bagi para investor dan pihak berkepentingan lainnya, penelitian ini juga menggunakan teori mengenai siklus akuntansi, konsep bank sampah, karakteristik UMKM diharapkan peneliti mampu memberikan solusi atas permasalahan pada bank sampah KALIBER dengan tujuan dibuatnya laporan keuangan pada bank sampah KALIBER yang sesaui dengan SAK-EMKM.

\section{Metode}

Penelitian ini merupakan jenis penelitian deskriptif kualitatif. Menurut Denzi \& Lincoln (1994) penelitian dengan menafsirkan fenomena/kejadian yang terjadi dilapangan yang dilakukan dengan menggunakan beberapa metode penelitian yang merupakan penelitian kualitatif. Metode analisis deskriptif kualitatif merupakan metode analisis yang digambarkan dengan kata-kata atau kalimat yang disajikan menurut kategori dengan maksud untuk memperoleh suatu simpulan (Husein Umar;1998)(Hardani et al. 2020) .

Teknik pengumpulan data yang dilakukan melalui wawancar,observai,studi pustaka dan dokumentasi. Peneliti melakukan wawancara sebagai subjek penelitian yaitu dengan Ketua Bank Sampah Kalibukbuk Bersih (KALIBER) di Desa Kalibukbuk yaitu Ketut Budiasa. SP dikarenakan pak ketut yang paling mengetahui mengenai proses pendirian, kegiatan, dan besarnya biaya yang dikeluarkan sehingga diyakini pak ketut bisa memberikan informasi yang dibutuhkan oleh peneliti. Subejek dalam penelitian ini juga dari beberapa pengurus bank sampah yaitu dari sekretaris dan bendahara yang mana sekretaris sebagai tangan kanan dari pak ketut tentunya informasi yang diperoleh dari sekretaris sebagai pendukung informasi yang diperoleh dari informan utama, secara umum bendahara sebagai pemegang keuangan sehingga dalam hal ini bendahara pada bank sampah menjadi informan penting pula dalam penelitian ini untuk mengetahui pencatatan yang telah dilakukan pada bank sampah KALIBER. Masyarakat yang terlibat dalam bank sampah tentunya dapat memberikan ingormasi mengenai pencatatan tabungan sampah yang dilakukan bank sampah terhadap nasabah, pemberiaan harga, dan informasi pendukung lainnya.

Data dan informasi yang diperoleh dalam penelitian ini yaitu mengenai jumlah nasabah dan cara pencatatan yang dilakukan pada bank sampah KALIBER dan untuk informasi yang diperoleh mengenai sistem kerja, pembagaian laba,penyebab belum dibuatnya pencatatan akuntansi pada bank sampah KALIBER. Untuk mendukung informasi yang diperoleh peneliti terjun langsung ke lokasi penelitian yaitu pada Bank Sampah KALIBER. Observasi ini dilakukan untuk lebih memahami mengenai kegiatan yang dilakukan pada bank Sampah KALIBER dengan terjun langsung dan melihat proses pencatatan dan kegiatan pengolahan sampah yang dilakukan pada Bank Sampah KALIBER.

Untuk mampu menyajikan informasi yang relevan peneliti menggunakan bantuan dari kajian teori yang bersumber dari buku yang terkait atau pendapat menurut para ahli untuk membantu dalam pemecahan pada permasalahan sehingga mampu membuat laporan keuangan dengan SAK EMKM. Dalam pengumpulan data melalui dokumentasi peneliti mengumpulkan data berupa catatan harga sampah, data nasabah berupa kartu tabungan, dan catatan terdahulu yang dilakukan oleh Bank Sampah KALIBER yang peneliti peroleh di Bank Sampah KALIBER. 


\section{Hasil dan Pembahasan}

\section{Profil Bank Sampah Kalibukbuk Bersih (KALIBER)}

Bank Sampah Kalibukbuk Bersih (KALIBER) yang menjadi objek penelitian telah berdiri sejak tahun 2017 didirikan oleh bapak Ketut Budiasa S.P. Bank Sampah Kalibukbuk Bersih (KALIBER) merupakan bank sampah unit binaan Dinas Lingkungan Hidup Kabupaten Buleleng yang diresmikan oleh Kepala Dinas Lingkungan Hidup Kabupaten Buleleng tanggal 12 Juni 2017 di kantor perbekel Desa Kalibukbuk dengan No SK 162/DLH/2017 dengan cara pengolahan sampah secara pribadi untuk mengajak masyrakat ikut berpartisipasi pada program-program yang ada,sistem pada KALIBER akan mengumpulkan, kemudian dipilih, dan dijual ke E-Darling sehingga masyarakat mendapatkan banefit dengan menabung sampah. Bank Sampah KALIBER beralamat di desa Kalibukbuk, dari tahun 2017 sampai saat ini nasabah Bank Sampah KALIBER sudah mencapai 873 itu termasuk instansi empat sekolah dasar, dua taman kanak-kanak dan satu SMP, dipercayai jumlah Bank Sampah KALIBER akan terus bertambah.

Bank Sampah KALIBER mempunyai inovasi untuk membangkitkan semangat generasi muda melestarikan lingkungan dan budaya dengan cara: Mengadakan bimbel/les tukar sampah,Mengadakan les tari tukar sampah,Membuat kerajinan tangan dari barang bekas dan Mengajak anak-anak difabel untuk membuat kerajinan dari barang bekas

\section{Struktur Organisasi}

Adapun struktur organisasi pada bank sampah KALIBER yang dipimpin bapak Ketut Budiasa S.P selaku ketua bank sampah KALIBER, dibantu oleh sekretaris yaitu Ketut Wilatika dan bendahara atas nama Putu Sumerta Yasa, S.Pd yang mana tugas meraka tidak pasti karena sisitem kerja pada bank sampah KALIBER tidak terikat waktu sehingga tugas mereka tidak terikat. Mengingat bila pada bank sampah KALIBER memiliki program mengadakan bimbel/les tukar sampah, mengadakan les tari tukar sampah,membuat kerajinan tangan dari barang bekas dan mengajak anak-anak difabel untuk ikut serta dalam kegiatan ini. Kegiatan ini merupakan program yang dimiliki oleh bank sampah KALIBER tentunya rutin terjadi sehingga dibuatlah bagan untuk masing-masing program tersebut.

\section{Kendala yang dihadapi Bank Kalibukbuk Bersih (KALIBER) dalam Menyusun Lapoan Ke uangan}

Berdasarkan hasil wawancara yang dilakukan memperoleh informasi bila kendala yang dihadapi Bank Sampah Kalibukbuk Bersih (KALIBER) dalam penyusunan laporan keuangan sesuai dengan SAK-EMKM yang disebabkan oleh :

1. Kurangnya pemahaman mengenai pembuatan laporan keuangan sesuai dengan SAKEMKM. Secara umum kurangnya pemahaman mengenai pembuatan laporan keuangan sesuai dengan SAK-EMKM disebabkan oleh rendahnya pemahaman dalam pencatatan akuntansi yang disebabkan oleh pendidikan yang diambil oleh pemilik dan pengurus dari bank sampah KALIBER tidak ada yang menjurus ke akuntansi sehingga mereka mengalami kesulitan dalam melakukan pencatatan akuntansi yang disebabkan pula karena belum ada sosialisasi yang memabahas mengenai pencatatan pada bank sampah sosialisasi yang pernah diadakan hanya membahas administrasi pada bank sampah seperti pencatatan nasabah dan pengelolaan sampah yang ada hal ini sesuai dengan hasil wawancara yang dilakukan pada pemilik bank sampah KALIBER yaitu

“... karena kurangnya pemahaman yang pak miliki dalam bidang akuntansi, pak kurang tau harus memulai dari mana akhirnya pak buat catatan sebatas yang pak 
ketahui dan mudah pak pahami. Ya itung itung pang koale pak nawang atas nama nasabah A nabung sampah be mone sebelihne pak kurang tau dik karena pencatatn ne pak gae tah sebatas ne dik"

2. Keterbatasan waktu. Terbatasnya waktu yang menjadi salah satau faktor belum dibuatnya laporan keuangan disebabkan karena pemilik dan pengurus dari bank sampah KALIBER memiliki pekerjaan lainnya yang tidak terfokus pada bank sampah KALIBER saja, hal ini sesaui dengan hasil wawancara yang dilakukan pada ketua bank sampah KALIBER yaitu:

“...karena pak rasa agak ribet yen ngae pencatatan akuntansi sampai laporan keuangan karena pak tulih-tulih di web agak ribet butuh waktu ne lama apalagi gae pak nak ink ngurusin ne den dik keto masi pegawai pak ngelah gae ne lenan ya akhirne kangguang pak gae tah sebatas mone dik".

\section{Pencatatan Akuntansi pada Bank Sampah KALIBER}

Aktivitas yang sering terjadi pada bank sampah KALIBER yaitu kegiatan pembelian sampah dari masyarakat yang disimpan dalam bentuk tabungan, penjualan sampah ke bank sampah induk E-Darling yang disimpan pula dalam bentuk tabungan, kegiatan yang mempengaruhi pengeluaran kas seperti penarikan tabungan oleh nasabah, pembayaran gaji karyawan, pembelian bensin dan pembayaran listrik dan air dan pula kegiatan yang mengakibatkan penambahan kas seperti penarikan tabungan ke bank sampah induk EDarling, penerimaan donasi dari donator dan biasanya dari kegiatan mengikuti lomba.

Aktivitas-aktivitas yang terjadi pada bank sampah kalibukbuk bersih (KALIBER) dicatat pada satu buku catatan yang merangkung keseluruhan aktivitas yang terjadi namun aktivitas yang biasanya dicatat adalah mengenai penerimaan dan penaraikan tabungan yang dilakukan oleh nasabah. Untuk aktivitas lainnya tidak dicatat oleh pihak bank sampah dikarenakan adanya kewjiban yang harus dibayar kepada para nasabah sehingga yang dicatat hanya jumlah sampah dan total pembelian sampah sehingga mengenai biaya gaji, biaya bensin, biaya listri dan air dan biaya overhead lainnya tidak dicatat oleh bank sampah KALIBER.

\section{Penyusunan Laporan Keuangan Berdasarkan SAK-EMKM}

Penyusunan laporan keuangan pada Bank Sampah Kalibukbuk Bersih (KALIBER) dibuat sesuai dengan kondisi dan data yang diperolah dari bank sampah KALIBER yang berpedomana pada Standar Akuntansi Keuangan Entitas Mikro Kecil dan Menengah (SAKEMKM). Pembuatan laporan keuangan disusun dari bulan Juli - Desember 2020 karena data yang diperoleh seperti catatan tabungan nasabah paling lengkap hal ini disebabkan karena transaksi baru terjadi disamping hal tersebut karena pihak bank sampah KALIBER tidak melakukan pencatatan biaya-biaya overhead yang dikeluarkan sehingga untuk biaya-biaya yang dikeluarkan diperoleh dari hasil wawancara yang telah dilakukan kepada bapak Ketut Budiasa S.P. Maka bapak Ketut Budiasa masih mengingat transaksi-transaksi yang pernah terjadi ditahun tersebut yang mana hal ini terjadi karena pencatatn yang dilakukan oleh bank sampah KALIBER belum terlalu lengkap sehingga dibutuhkan kemampuan ingatan dari bapak Ketut Budiasa.

Secara umum penyusunan laporan keuangan dimulai dari membuat jurnal baik itu jurnal umum ataupun jurnal khusu, hingga membuat laporan keuangan yang terdiri dari laporan perubahan ekuitas,laba rugi,laporan posisi keuangan,arus kas dan catatan atas laporan 
keuangan namun dalam SAK-EMKM cukup dengan membuat laporan laba rugi,neraca dan catatan atas laporan keuangan.

\section{Laporan Laba Rugi}

Berikut merupakan laporan laba rugi pada bank sampah kalibukbuk bersih (KALIBER) yang sesuai dengan SAK EMKM

\begin{tabular}{|c|c|c|c|c|}
\hline & $\begin{array}{l}\text { K SA } \\
\text { POR } \\
\text { e Juli }\end{array}$ & $\begin{array}{l}\text { AH KALIBER } \\
\text { LABA RUGI } \\
1 \text { Desember } 2020\end{array}$ & & \\
\hline \multicolumn{5}{|l|}{ Pendapatan } \\
\hline Pendapatan Penjualan & $\mathrm{Rp}$ & 678.200 & & \\
\hline Pendapatan lain-lain & $\mathrm{Rp}$ & 9.000 .000 & & \\
\hline Jumlah Pendapatan & & & $\mathbf{R p}$ & 9.678 .200 \\
\hline Harga Pokok Penjualan & & & $\mathrm{Rp}$ & $(391.700)$ \\
\hline Laba Kotor & & & $\mathbf{R p}$ & 9.286 .500 \\
\hline \multicolumn{5}{|l|}{ Beban Usaha } \\
\hline Biaya Perlengkapan & $\mathrm{Rp}$ & 70.000 & & \\
\hline Biaya Gaji Karyawan & $\mathrm{Rp}$ & 2.400 .000 & & \\
\hline Biaya Bensin & $\mathrm{Rp}$ & 150.000 & & \\
\hline Biaya listrik\&air & $\mathrm{Rp}$ & 228.000 & & \\
\hline Biaya Penyt. Kantor & $\mathrm{Rp}$ & 1.250 .000 & & \\
\hline Biaya Penyt. Gudang & $\mathrm{Rp}$ & 750.000 & & \\
\hline Biaya Penyt Perlatan & $\mathrm{Rp}$ & 74.800 & & \\
\hline Biaya Penyt Kendaraan & $\mathrm{Rp}$ & 2.187 .500 & & \\
\hline Jumlah Biaya Usaha & & & $\mathrm{Rp}$ & 7.110 .300 \\
\hline \multicolumn{3}{|c|}{ LABA USAHA } & $\mathbf{R p}$ & 2.176 .200 \\
\hline
\end{tabular}

Sumber : Catatan keuangan Bank Sampah KALIBER (data di olah)

\section{Laporan Posisi Keuangan}

Berikut merupakan laporan posisi keuangan pada bank sampah kalibukbuk bersih (KALIBER) yang sesuai dengan SAK EMKM

\section{LAPORAN POSISI KEUANGAN}

Periode Juli - 31 Desember 2020

AKTIVA

\section{Aktiva Lancar}

Kas

Donasi

Piutang usaha

Persediaan

Perlengkapan

Jumlah Aktiva Lancar

Aktiva Tetap

Kantor

$\begin{array}{rr}\text { Rp } & 4.531 .800 \\ \mathrm{Rp} & 6.000 .000 \\ \mathrm{Rp} & 770.150 \\ \mathrm{Rp} & 1.614 .600 \\ \mathrm{Rp} & 75.575\end{array}$

Rp

12.992.125

Rp $\quad 50.000 .000$ 


$\begin{array}{llr}\text { Akm.Penyt.Kantor } & \mathrm{Rp} & (2.500 .000) \\ \text { Gudang } & \mathrm{Rp} & 30.000 .000 \\ \text { Akm.Penyt.Gedung } & \mathrm{Rp} & (1.500 .000) \\ \text { Mobil Pick Up } & \mathrm{Rp} & 35.000 .000 \\ \text { Akm.Penyt.Mobil } & \mathrm{Rp} & (4.375 .000) \\ \text { Peralatan } & \mathrm{Rp} & 748.000 \\ \text { Akm.Penyt.Peralatan } & \mathrm{Rp} & (149.600) \\ \text { Jumlah Aktiva Tetap } & & \end{array}$

TOTAL AKTIVA

PASIVA

\section{Hutang Lancar}

\begin{tabular}{lrrrr} 
Utang sampah & Rp & 3.039 .325 & & \\
Jumlah H.Lancar & & & Rp & $\mathbf{3 . 0 3 9 . 3 2 5}$ \\
$\begin{array}{l}\text { Equity } \\
\text { Modal Pak Ketut }\end{array}$ & $\mathrm{Rp}$ & 115.000 .000 & & \\
Laba Usaha & $\mathrm{Rp}$ & 2.176 .200 & & \\
Jumlah Equity & & & $\mathbf{R p}$ & $\mathbf{1 1 7 . 1 7 6 . 2 0 0}$ \\
& & & $\mathbf{R p}$ & $\mathbf{1 2 0 . 2 1 5 . 5 2 5}$ \\
\hline \hline
\end{tabular}

Sumber : Catatan keuangan Bank Sampah KALIBER (data di olah)

\section{Catatan Atas Laporan Keuangan}

\section{BANK SAMPAH KALIBER}

\section{CATATAN ATAS LAPORAN KEUANGAN}

Periode Juli - 31 Desember 2020

1. UMUM

Bank Sampah Kalibukbuk Bersih (KALIBER) beralamat di Desa Kalibukbuk Kec/Kab Buleleng . Bank Sampah KALIBER merupakan bank sampah unit binaan Dinas Lingkungan Hidup Kabupaten Buleleng yang diresmikan pada tanggal 12 Juni 2017 di kantor perbekel Desa Kalibukbuk dengan No SK 162/DLH/2017.

2. IKHTISAR KEBIJAKAN AKUNTANSI

Adanya pernyataan kepatuhan bila laporan keuangan yang dibuat sesuai dengan SAKEMKM dengan adanya dasar penyusunan laporan keuangan.

3. PENJELASAN AKUN-AKUN PADA LABA RUGI

Pendapatan yang diterima dari kegiatan Bank Sampah KALIBER yaitu melalui penjualan sampah, penerimaan donasi, dan pemenangan lomba. Berikut merupakan penjelasan dari akun-akun pendapatan pada laporan laba rugi.

a. Pendapatan penjualan sampah

Dari laporan laba rugi menunjukkan bila perolehan penjualan sampah sebesar Rp 678.200 yang rinciannya diperoleh dari jurnal penjualan sampah bulan juli - 31 desember 2020 yaitu di bulan agustus dengan melakukan penjualan sampah $30 \mathrm{~kg}$ sampah plastik bentukan campur @ Rp 1.500, 4kg aqua gelas bersih @ Rp 6.000, dan 5kg ale-ales@ Rp 10.000 dengan total penjualan bulan agustus Rp 79.000. Penjualan di bulan oktober sebesar Rp 287.200 dengan rincian penjualan yaitu 80kg plastik bentukan ades@ @p 2.000,19 kg aqua gelas kotor, 1kg ale-ale @ Rp 2.000,35kg kardus @1.500, 9kg buku@Rp 300, dan 15 kg botol kaca@ @p 1.500 dengan total penjualan bulan 
oktober Rp 287.200. Penjualan bulan desmber sebesar Rp 312.000 dengan rincian penjualan yaitu 4kg plastik gelas @ Rp 2.000, 7kg aqua bersih @ Rp 6000, 50kg buku @Rp 500,5kg kardus@Rp 1000, 12 kg buku@Rp 1500, 100kg plastik daunan campur@Rp 700, 50kg plastik kotor Rp 700, 20kg plastik bening @ Rp 1500, 1kg aliminium @ Rp 8000, 25 kg botol @ Rp 600, dan 4kg botol besar @ Rp 1500 dengan total penjualan dibulan desember Rp 312.000.

b. Pendapatan lain-lain

Pendapatan lain-lain yang diperoleh dari bulan dari juli - 31 desember 2020 sebesar Rp 9.000.000, yang diperoleh dari donasi yang tidak tetap donasi yang diterima dari bulan juli sampai bulan desember sebesar Rp 5.000.000 dan dari perolehan lomba bulan oktober sebesar Rp 4.000.000. Beban usaha pada bank sampah KALIBER yaitu:

c. Biaya perlengkapan.

Biaya perlengkapan yang terjadi diakibatkan oleh penyesuaian diakhir periode sebesar Rp 70.000.

d. Biaya Gaji Karyawan. Bank sampah KALIBER memiliki 2 karyaan aktif, yaitu sekretaris dan bendahara per minggu mereka diberi gaji Rp 50.000 sehingga untuk 1 bulan biaya gaji yang dikealurkan oleh pak Ketut Budiasa sebesar 4xRp $50.000=\mathrm{Rp}$ 200.000 @ 2orang = Rp400.000. Sehingga biaya gaji yang dikeluarkan per smester 6xRp $400.000=\operatorname{Rp} 2.400 .000$

e. Biaya Bensin. Biaya bensin dikeluarkan akibat dari kegiatan penjemputan sampah nasabah yang mana biaya ini dikeluarkan setiap jalan sebesar Rp 50.000 sehingga total biaya bensin yang dikeluarkan di akhir periode sebesar Rp 150.000.

f. Biaya listrik \& air. Biaya listrik \& air merupakan biaya yang dikeluarkan dari kegiatan kantor dan dari kegiatan yang dilakukan di gudang, perbulan diperkirakan mengeluarkan biaya untuk listrik dan air sebesar Rp 38.000 sehingga total biaya yang dikelaurkan untuk bulan juli - desember 2020 sebesar Rp 228.000

g. Biaya Penyusutan Kantor. Sesuai dengan kebijakan akuntansi yang telah dijabarkan sebelumnya bila metode penyusutan yang digunakan yaitu metode garis lurus. Dengan diketahui bila pembangunan kantor tersebut diperkirakan mengeluarkan biaya $\mathrm{Rp}$ 50.000.000 dengan taksiran umur ekonomis 20 tahun. Sehingga perhitungan biaya penyusutan kantor adalah sebagau berikut: Rp 50.000.000/240*6 bulan $=\mathrm{Rp}$ 1.250.000 penyusutan setiap 6 bulan

h. Biaya Penyusutan Gudang. Sesuai dengan kebijakan akuntansi yang telah dijabarkan sebelumnya bila metode penyusutan yang digunakan yaitu metode garis lurus. Diperkirakan biaya yang dikelaukan dalam pembangunan gedung tersebut sebesar $\mathrm{Rp}$ 30.000.000 dengan taksiran umur ekonomis 20 tahun. . Sehingga perhitungan biaya penyusutan gudang adalah sebagau berikut: Rp 30.000.000/240*6 bulan $=\operatorname{Rp} 750.000$ penyusutan setiap 6 bulan

i. Biaya Penyusutan Kendaraan. Bank sampah KALIBER hanya memiliki satu kendaraan pengangkutan yang diperkirakan bila harga perolehan mobil pik-up sebesar Rp 35.000.000 dengan taksiran umur ekonomis 8 tahun. Sehingga perhitungan biaya penyusutan kendaraan adalah sebagau berikut: Rp 35.000.000 / $96 * 6$ bulan $=\mathrm{Rp}$ 2.187.500 penyusutan setiap 6 bulan

j. Biaya Penyusutan Peralatan. Peralatan yang digunakan pada Bank sampah KALIBER yaitu 2 gerobak sampah dengan harga Rp 300.000, peralatan 4 timbangan kecil dengan harga $\mathrm{Rp} 98.000$ dan 1 tibangan besar dengan harga Rp 30.000 dengan perkiraan umur ekonomis 5 tahun. Sehingga perhitungan biaya penyusutan peralatan adalah sebagau berikut: $\operatorname{Rp} 748.000 / 90 * 6$ bulan $=\operatorname{Rp} 75.800$ penyusutan setiap 6 bulan 


\section{PENJELASAN AKUN-AKUN PADA NERACA}

A. Aset

a. Kas. Kas pada Bank Sampah KALIBER Rp 4.531.800, di akhir Juni sebesar Rp 3.250.000 dengan penambahan kas melalui penarikan tabungan pada bank sampah Edarling dan pemenangan lomba sebesar Rp 4.600.000 dan adanya pengurangan kas yang disebabkan oleh kegiatan operasional bank sampah Rp 3.318.200 hal ini dapat dilihat pada jurnal penerimaan dan pengeluaran kas.

b. Donasi. Dari laporan neraca menunjukka bila di akhir tahun 2020 bank sampah KALIBER menerima donasi $\mathrm{Rp} 6.000 .000$ yang diperoleh dari neraca saldo sebelumnya dengan nominal Rp 1.000.000 dan dari bulan Juli sampai Desember menerima donasi sebesar Rp 5.000.000 maka total donasi yang diterima sebesar Rp 6.000 .000

c. Piutang Usaha. Diakhir periode jumlah piutang usaha sebesar Rp 770.150 yang mana angka ini diperoleh dari neraca saldo sebelumnya sebesar Rp 691.950. Di tanggal 15 agustus bank sampah Kaliber melakukan penarikan tabungan sebesar Rp 600.000 sehingga melalui penarikan ini terjadi akibat pengurangan saldo piutang menjadi $\mathrm{Rp}$ 91.950 dan bank sampah KALIBER di 6 bulan ini melakukan penjualan/penyetoran sampah ke E-Darling sebesar Rp 678.200 sehingga saldo piutang usaha diakhir periode sebesar Rp 770.150.

d. Persediaan sampah

Pada laporan posisi keuangan menunjukkan bila persesiaan sebesar Rp 1.614 .600 yang diperoleh dari neraca saldo sebelumnya $\mathrm{Rp} 188.000$, untuk pembelian sampah yang dilakukan dari bulan juli - desember sebesar Rp 1.818.300 dengan penjualan sampah sebesar Rp 391.700 sehingga total persediaan di akhir periode sebesar Rp 1.614.600.

e. Perlengkapan. Perlengkapan pada bank sampah KALIBER diakhir periode sebesar Rp 75.575 dengan rincian dari neraca saldo sebesar Rp 145.575 namun diakhir bulan perlengkapan yang ada sebesar Rp 75.575 sehingga dilakukan penyesuaian sebesar Rp 70.000

B.Liabilitas

a. Hutang Usaha. Hutang usaha yang dimiliki bank sampah KALIBER akibat dari adanya pembelian sampah secara kredit besarnya hutang tersebut diakhir periode sebesar Rp 3.039.325 yang diperoleh dari neraca saldo sebelumnya yaitu $\mathrm{Rp} 1.731 .225$, melakukan pembelian sampah secara kredit dari bulan juni-desember sebesar Rp 1.818.300 dan dilakukannya penarikan tabungan oleh nasabah sebesar Rp 510.200 sehingga total hutang usaha sebesar Rp 3.039.325.

C.Equitas

a. Modal Pak Ketut. Modal yang dikealurkan pak Ketut Budiasa sebanyak Rp 115.000.000 yang berasal dari dana pribadi pak Ketut.

b. Laba Usaha. Laporan posisi keuangan menunjukkan bila laba usaha yang diperoleh sebesar Rp 2.176.200 yang diperoleh dari pengurangan antara pendapatan dan beban usaha yang ditunjukkan pada laporan laba rugi dan laporan neraca lajur.

Implikasi Penyusunan Laporan Keuangan Sesuai Dengan SAK-EMKM pada Bank Sampah KALIBER 
Berdasarkan hasil penelitian yang telah dilakukan pada Bank Sampah Kalibukbuk Bersih (KALIBER) di desa Kalibukbuk Kec/Kab Buleleng dapat diuraikan implikasi sebagai brikut:

a.Laporan keuangan yang dibuat sesaui dengan SAK-EMKM dapat memberikan pemahaman para pelaku bisnis khusunya pada anggota bank sampah KALIBER dalam pmbuatan laporan keuangan yang seharusnya diterapkan.

b. Dibuatnya laporan keuangan yang sesuai dengan SAK-EMKM mempermudah pemilik bank sampah KALIBER dalam melakukan kredit untuk menunjang kegiatan operasional bank sampah KALIBER.

c. Pemilik bank sampah KALIBER dapat mengetahui kinerja keuangan dengan peningkatan pada kualitas pengelolaan keuangan yang diterapkan.

d.Pengetahuan akan perkembangan bank sampah dari waktu ke waktu dapat diketahui baik itu melalui peningkatan jumlah nasabah dan peningkatan pendapatan

e. Meminimalisir perolehan kerugian sehingga kebangkrutan dapat dihindari.

\section{Simpulan dan Saran}

Dari penelitian yang sudah dilakukan maka ada beberapa hal yang menjadi simpulan dalam penelitian ini, yaitu: rendahnya pemahaman dalam pencatatan akuntansi oleh pengurus KALIBER dan terbatasnya waktu yang dimiliki yang disebabkan karena adanya pekerjaan lain yang harus diambil di hari kerja mengakibatkan pencatatan akuntansi yang dilakukan belum sesuai dengan SAK-EMKM sehingga dari permasalahan tersebut peneliti menekankan pada beberapa tahap pencatatan yang sesuai dengan siklus akuntansi dan SAK-EMKM dengan memberikan pedoman pencatatan akuntansi dari bulan Juli - 31 Desember dengan transaksi yang peneliti peroleh dari bank sampah KALIBER. Jurnal khusus sebagai pencatatan transaksi yang peneliti pilih dengan membuat laporan keuangan berupa laba rugi pada bank sampah KALIBER mencangkup penerimaan dan pengeluaran yang mana laba yang diperoleh oleh bank sampah KALIBER sebesar Rp 2.176.200 laporan neraca mencakup asset, liabilitas dan equitas yang dimiliki oleh perusahaan dengan total aktiva dan pasiva pada bank sampah KALIBER sebesar Rp 120.215.525 dan catatan atas laporan keuangan (CaLK) yang disajikan informasi secara kualitatif mengenai keadaan pada bank sampah KALIBER. Implikasi dengan adanya laporan kuangan dengan SAK-EMKM, pihak bank sampah KALIBER mengetahui dengan baik keadaan keuangannya untuk menghindari kebangkrutan dimasa mendatang sehingga bisa dilakukan pengelolaan keuangan dengan baik. Dari yang telah diuraikan penulis membantu pihak bank sampah KALIBER untuk dapat memahami mengenai penyusunan laporan keuangan dengan SAK-EMKM dengan adanya laporan keuangan yang dibuat maka dapat memberikan peluang bagi bank sampah untuk memberikan informasi keuangan pada pihak yang berkepentingan sehingga mempermudah memperoleh suntikan dana dari pihak investor yang sesaui dengan teori sinyal dan terjalinnya hubungan antara pemilik perusahaan dengan karyawan dengan imbalan yang sesaui diberikan jika mengacu pada teori agensi. Dalam penyusunan laporan keuangan dibuat sesaui dengan siklus akuntansi dan menyesuaikan dengan kondisi yang ditemui pada bank sampah KALIBER sehingga dihasilkan laporan keuangan yang yang mudah dipahami dan sesuai dengan dilapangan

Adapun beberapa saran yang dapat penulis sampaikan bagi pemerintah, permasalahan yang ditemui dilapangan yaitu belum dibuatnya laporan keuangan yang memadai yang disebabkan karena kurangnya pemahaman mengenai pencatatan akuntansi sehingga dalam hal ini diharapkan lembaga pemerintah yang terkait dapat lebih genjar dalam mengadakan sosialisasi mengenai pencatatan akuntansi sehingga permasalahan ini dapat sedikit teratasi. Saat ini bank sampah mulai diminati oleh masyarakat khusunya pada bank sampah 
KALIBER dengan samakin meningkatkan aktifitas dan peningkatan jumlah nasabah pada bank sampah seharusnya pencatatan akuntansi harus lebih diperhatikan agar diketahui dengan pasti mengenai keadaan keuangan pada bank sampah maka dari itu saran yang dapat peneliti sampaikan diharapkan kedepannya bank sampah KALIBER mampu meneruskan dalam pembuatan laporan keuangan yang sesuai dengan SAK-EMKM sehingga dengan adanya laporan keuangan dapat membantu bank sampah KALIBER dalam melakukan pengelolaan keuangan untuk meminimalisir kerugian yang diperoleh sehingga bank sampah KALIBER dapat terus berdiri. Dalam suatu penelitian tentuanya akan selalu adanya suatu keterbaharuan maka dari itu untuk peneliti selanjutnya diharapkan mampu memberikan sumbangan pencatatn akuntansi berbasis computer/menggunakan aplikasi dalam pencatatan transasksi hingga menghasilkan laporan keuangan tentunya hal ini akan sangat mempermudah pihak bank sampah dalam penyusunan laporan keuangan.

\section{Daftar Pustaka}

Azzahra, T. A. 2020. "No Title." Menteri Lhk: Timbunan Sampah di Indonesia Tahun 2020 Capai 67,8 Juta Ton.

Dinas Lingkungan Hidup Kabupaen Buleleng. 2019. "Jumlah Bank Sampah Dan Tps Provinsi Bali." Jumlah Bank Sampah Dan Tps Provinsi Bali.

Fitria, A N I. 2017. "Dalam Perspektif Etika Bisnis Islam Oleh : Jurusan : Ekonomi Syari' Ah ( Esy ) Fakultas : Ekonomi Dan Bisnis Islam Institut Agama Islam Negeri ( IAIN ) METRO 1438 H / 2017 M.” Institut Agaa Islam Negeri (IAIN).

Hardani, Nur Hikmatul, Helmina Andriai, and Asri Fardani. 2020. Meode Penelitian Kualtatif\&Kuantitatif. 1st ed. ed. Husnu Abadi. Yogyakarta.

Sekar ayuning thias. 2018. "Program Studi Hukum Ekonomi Syari ' Ah Fakultas Syari ' Ah Dan Hukum Universitas Islam Negeri Raden Fatah Palembang."

Undang-Undang Republik Indonesia No 20 tentang UMKM. 2008. Undang-Undang Republik Indonesia No 20 Tahun 2008 Tentang UMKM. 